\title{
Relationship between Occupational Health Hazards and the Use of Safety Measures among Workers in Textile Factory in Port Said City
}

\author{
Ateya M. Ibrahim, D.N.Sc.*; Effat M. El-Karmalawey, D.N.Sc.; Hassan Abd \\ El-Wahid, M.D.; and Fatma El-Emam Hafez, D.N.Sc.*
}

The department of Family and Community Health Nursing, Faculty of Nursing, Port Said University*; Community Health Nursing, Faculty of Nursing, Cairo University and Community Medicine, Faculty of Medicine, Suez Canal University

\begin{abstract}
Background: Workers at textile factories are exposed to different hazards, which may have tremendous harmful effects on their health.

Aim: The aim of the study was to evaluate the relationship between occupational health hazards and the use of safety measures among workers in textile factory in Port Said city.

Materials and Methods: A cross sectional descriptive design was utilized to conduct this study. The study sample was carried on 100 workers in a textile factory in Port Said city. The data were collected using three tools: Structured Interviewing Questionnaire, an observational checklist and an environmental safety checklist.

Results: The results of this study showed that that more than three quarters (77\%) of the study group was exposed to psychological hazards while about two thirds (64\%) were exposed to physical hazards. Moreover, almost two-thirds (66\%) of the study group didn't use different protective devices.

Conclusion: The study concluded that there was a highly significant difference between exposure of the studied group to various types of occupational health hazards and not wearing personal protective equipments $(\mathrm{p} \leq 0.05)$. It is recommended that the need for stressing on the application of International Standard Occupational Health and Safety Assessment Series in field work to improve occupational health and safety performance for the workers and emphasizing on the importance and usefulness of personal protective equipment to be used in the right way.
\end{abstract}

Keywords: Occupational health hazards, Personal protective equipment, Textile factory 


\section{Introduction}

FACTORIES represent one of the most important strategic manufactures and a basic element in the economic development of any country. Workers in the sector factories constitute an important productive and aggregate in the community (David et al., 2005 and Baskett, 2007).

Work is viewed as important to one's life experience; most adults spend about fulfilling one third of their time at work. About $45 \%$ of the world's Population and $58 \%$ of the population over 10 years of age constitute the global workforce (Rogers, 2005 and Gupta \& Ghai, 2007).

Work when fulfilling, fairly compensated, healthy and safe can help to build long and contented lives and strengthen families and community. No work is completely risk-free and all health care professionals should have some basic knowledge about workforce populations, work and related hazards and methods to control hazards and improve health (Stanhope \& Lancaster, 2008).

Workers exposed to different hazards, which may have tremendous harmful effects on their health. These hazards may result from physical, chemical or mechanical agents (ElSobky, 2008). Work-related injuries present a major public health problem resulting in serious social and economic consequences that could be prevented if appropriate measures are taken (Ahn, Bena \& Bailer, 2004).

Studies in industrial countries reveal that the causing agent of $90 \%$ of workplace accidents is human error and only $10 \%$ of those belong to unsuitable workplace and equipment (Fleming \& Lardner, 2002). Workers often need to wear protective equipment to be protected from Injury, illness and death caused by exposure to workplace hazards (American Association of Occupational Health Nurses (AAOHN), 2007).

According to labor law legislation, employers are obliged to take all necessary safety measures and make available all equipment required to ensure occupational health and safety at workplaces. In order to ensure compliance with and supervision of the measures taken for occupational health and safety at the workplace, the employers must keep the employees informed regarding occupational risks they are exposed, inform the employees of their legal rights and obligations and provide training to the employees on issues related to occupational health and safety (WHO, 2003). 
Textile industry is one of the most vital industries in Egypt. The workers are exposed to different environmental factors, especially in the spinning and weaving sections, which play a role in the high incidence of industrial health hazards (Burkean, 2009). The most important hazards are the air borne cotton dust, excessive noise, accidents and skin diseases. Cotton dust is high in spinning operation; it has a local action on respiratory tract and can cause byssinosis and occupational pulmonary disease (Conn \& Barclay, 2008).

Occupational health nurse has a major role in identifying occupational hazards, determining workers health problems, early case finding, management and referral to the appropriate community health resources (Plog et al., 2004, Mercury et al., 2009). As well, the occupational health nurse analyzes each job task to detect task situations that place employee at risk through assessment and surveillance of the workplace to identify Potential hazards increasing with the work, reducing risk, and minimizing risk problems (Harris, 2007).

\section{Significance of the Study:}

Annually, throughout the world, an estimated number of 271 million people suffer from occupational health hazards, and 2 million die as consequence of these hazards. In addition, the estimated economic loss caused by work related hazards and diseases was equivalent to $4 \%$ of the world's gross national Product (WHO, 2003). In Egypt it is expected that this problem could be maximized as a result of the large number of workers in the textile factory, it is estimated that about 1,750,000 of total workers employed in textile factories in Egypt (Central Agency for Public Mobilization and Statistics, 2006). So the investigator decided to shed the light on such occupational health hazards among textile workers in Port Said City.

\section{Aim of the study:}

To evaluate the relationship between occupational health hazards and the use of safety measures among workers in textile factory in Port Said City.

\section{Materials and Methods}

Study Design: A descriptive cross-sectional research design was used.

Setting: The study was carried out in a textile factory in Port Said city which consists of six small sections according to textile industry process, namely (fiber preparation, spinning, weaving, pretreatment, dyeing, printing and finishing sections).

Sample: The study sample was carried on 100 workers in a textile factory in Port Said city. Data collection took a period of 3 months from April to July 2013. 


\section{Data collection tools:}

Tool (I): Structured Interviewing Questionnaire: This tool was developed by the investigator and includes:

A- Socio-demographic characteristics of textile factory workers: such as (age, family numbers, room numbers, level of education, marital status, income, sleep hours and physical activity).

B- Work data: such as (daily working hours, years of experience, work shifts, position during work, and work accidents).

C- Data about health habits: such as (personal hygiene in and outside factory, and smoking habits).

D- Medical history of the workers (History of hypertension, heart diseases, diabetes......).

E- Data about safety measures (Overall uniform, head cover, ear muff.......).

F-Data about health services: such as (first aids provided, place of worker examination, and time of periodic examination).

G- Recreational activities (Clubs, beach, trips........).

H- Data about occupational hazards (Physical, chemical, ergonomic, and psychological) hazards.

Tool (II):

An observational checklist developed by Hagag (1995) to assess workers use for different personal protective clothes such as (overall uniform, head cover, eye goggles, gloves, protective apron, safety boots and respiratory mask).

Tool (III):

An environmental safety checklist which developed by Hagag (1995) to assess the factory work environment and includes data about light, ventilation, noise, space between machines, cleanliness, and emergency exit facilities).

\section{Results}

Table (1) shows distribution of the study group according to their socio demographic data. As evident in the table, almost one third (32\%) aged between 30 to less than 40 years and the lowest percentage $(8 \%)$ for age under 20 years, with a mean age $34.98 \pm 10.3$ years Concerning marital status, it was found that more than two thirds(71\%) of the study group were married. As regards to level of education, it was found that two-thirds $(66 \%)$ of the study group had secondary or industrial education, while $7 \%$ of the study group were illiterate. 
Table (2) demonstrates distribution of the study group, according to characters of work, as shown in the table, the highest percentage of the study group (42\%) were working morning shifts and the lowest percentage (19\%) were working on afternoon shifts, while more than one third (39\%) of the study group had more than one shift. It also observed that working hours ranged from 6 to 12 hours per day with a median of 7.50 hours. In relation to years of experience, more than half $(52 \%)$ of the study group had experience more than10 years, while those who had experience less than or equal one year were $7 \%$. As regards to the position of the study group during work, more than half of them were working in a standing position, while those who worked in a sitting and bending positions were $36 \%$ and $7 \%$ respectively.

Figure (1) illustrates distribution of the study group according to their attendance to training courses, as shown in the figure, more than half (56\%) of the study group did not attend any training courses.

Table (3) reveals distribution of the study group according to their exposure to occupational health hazards. As shown in the table, it was noticed that more than three quarters (77\%) of the study group were exposed to psychological hazards, nearly three fourths $(74 \%)$ were exposed to chemical hazards, while those who exposed to mechanical and physical hazards were $72 \%$ and $64 \%$ respectively.

Table (4) reveals distribution of the study group according to their report about the availability of personal protective measures. As it noticed in the table, it was found that most of the personal protective equipment such as ear muffs, and over all uniform, gloves, respiratory mask, protective apron, safety boots, and head covers were unavailable in the following percentages $95.0 \% .92 .0 \%, 92.0 \%$. $74.0 \%, 73.0 \%, 71.0 \%$ and $69.0 \%$ respectively

Table (5) reveals the relationship between exposure of the study group to occupational health hazards and the use of personal protective equipments. As it noticed in the table, there was a highly statistically significant difference between exposure of the study group to occupational health hazards and the use of safety protective equipment.

Table (6) reveals the relationship between level of education of the study group and their attendance to training courses. As evident in the table, it was observed that there was a statistically significant difference between level of education of the study group and their attendance to training courses about occupational health hazards, while there was no a statistically significant difference between level of education of the study group and their attendance to training courses about accidents prevention and first aids respectively. 
Table (7) detects relationship between personal characters of the study group and their exposure to various types of occupational health hazards. As shown in the table, it was observed that there was a statistically significant difference between age categories of the study group and their exposure to physical, chemical, psychological and mechanical hazards respectively. It also observed that, there was a statistically significant difference between level of education of the study group and their exposure to physical, chemical, and mechanical hazards respectively, while on the other hand, as noted in the table, there was no a statistically significant difference between sleep hours the study group and their exposure to various types of occupational health hazards.

\section{Discussion}

As the world continues its voyage towards modernization, it faces tremendous challenges of the $21^{\text {st }}$ century. The rapid growth in the industry globally has raised concern on safety and health issues in the workplace. As a result, more occupational accidents and injuries at workplace make headline news all over the globe (Khdair et al., 2011). These hazards may result from physical, chemical, biological, psychosocial and/or ergonomic factors (ConchaBarrientos et al., 2004). The occupational health nurse has a major role in controlling and preventing exposure to these hazards by determining workers' health problems, identifying industrial health hazards and dangerous conditions for health, planning, promoting workers' health, providing appropriate treatment, and initiating appropriate safety measures (OHSA, 2006; Mercury et al., 2009).

This study was carried out for the purpose of evaluating the relationship between occupational health hazards and the use of safety measures among workers in textile factory in Port Said city. To discuss the results of the current study, the focus was on exposure of the studied group to different types of occupational health hazards and its effects on health, safety protective equipment, and the relationship between occupational health hazards and the use of safety measures among workers in the textile factory.

Concerning to the socio demographic data of the study group, it was observed that, nearly a third of them were in the age group between 30 to less than 40 years, more than two thirds of them were married, and two thirds of the study group had a secondary or industrial education. It also revealed that, the median of family members per room was two members, more than three fourth of the study group reported that they hadn't enough income. As well as more than, half of them had an experience more than ten years. 
The current study revealed that more than three fourths of the study group were exposed to psychological hazards, nearly third quarters of them were exposed to chemical and mechanical hazards respectively, while whom exposed to physical hazards were approximately two thirds of the study group. These results are supported by findings of researches of Jamison et al., (2006); Sivarethinamohan (2010); Malik et al., (2010) ; Koka and Srivastava (2012); Marmot and Blatt (2013) that the workers expose to various types of occupational health hazards in their workplace such as physical, chemical, mechanical and psychological hazards. In addition, Rantanen (2004) who conducted a study about health and safety workplace in Finland, revealed that still 20\%-30\% of the workers in the industrialized countries, and up 50-70\% of the working people in developing countries are exposed to traditional physical-chemical, ergonomic and safety hazards. These findings might be due to, lack of awareness about the hazards of their occupations, general backwardness in sanitation, poor nutrition, lack of orientation about the universal precautions of the occupational health hazards in addition to lack of training program attendance.

Concerning workers wearing personal protective equipment (PPE), the findings of the present study had revealed that almost two thirds of the studied group were not wearing PPE. This result is in agreement with Shafik and Abed El-Mohsen (2012) who conducted a study about Health Promotion Program to Improve Health Workers in Torah Cement Factory, Egypt; found that almost two thirds of the studied workers were not wearing safety measures. Moreover, Sheha (2009) who conducted a study about Occupational Hazards among Workers in Glass Manufactures Industries, Egypt, reported that more than three quarters of the studied group weren't wearing PPE.

The finding of the current study showed that less than one tenth of the study group was wearing safety gloves, which was incongruent with the results of Tarvsainen et al., (2006) who found that $94 \%$ of the studied workers used protective gloves. The present results revealed that a minority of the studied workers was wearing earring muff which comes into agreement with Sarok and Susil (2012), who carried out a study about Occupational Hazards in the Workplace: Malaysia, and revealed that the minority of workers were using ear plugs. On the contrary, the results of Moore (2007), who carried out a survey of 998 noisy factories in New Zealand, showed that $43 \%$ of the workers actually wore the hearing protectors provided. 
Concerning the availability of PPE, the majority of the studied group reported that PPE were not enough in their work area. This finding, on the same line with Shafik and Abd El-Mohsen (2012), who found that a high percentage of the studied sample accounting for more than three quarters reported that the PPE were not enough in their work area, while it increased to be available representing the majority post program. Furthermore, results of the studied group revealed that, in spite of some PPE presence, it wasn't used which might be explained by the lack of administrative follow up for specialized employees responsible for this role. These findings might be explained by the lack of training and insufficient safety measures in the factory, non periodic checking about PPE, lack of administrative follow up.

Regarding the relationship between exposure of the studied group to various types of occupational health hazards in their workplaces with the use of personal protective equipment. The findings of the present study revealed that there was a highly statistically significant difference between exposure of the study group to various types of occupational health hazards in their workplaces without wearing personal protective equipment. This finding is in agreement with Sheha (2009) who indicated that, there was a highly statistically significant difference between occupational diseases and not wearing personal protective equipment. Also, in another study, Kotb (2012) concluded that there was a highly significant complaint in workers who weren't using personal protective devices than those who were using it. On the other hand, Boonmak (2009) who carried out a study about Occupational Accidents and Risk Behavior Among Wooden Game Workers, and revealed that occupational accidents had a significant relationship with total risk behaviors and not only using personal protective equipment was found to have a significant relationship with occupational accidents.

The findings of the present study revealed that there was a statistically significant difference between personal characters of the study group (Age and level of education) and their exposure to various types of occupational health hazards in their workplaces. These findings are in agreements with Tiwari et al., (2004), who revealed that workers above 35 years of age had lower back pain compared to less than 35 years aged workers. Moreover, Feijoo (2004) viewed the influence of age on stress level among 200 subjects suffering from job insecurity, the result revealed that age had significant influence on the stress level of workers.

In addition, Bhatia and Kumar (2005) studied the influence of age on experience burn out, the sample consisted of 100 employees from textile industries in Bhiwani, the study revealed that the employees who were aged 32-42 years experience more burnout than employees of 
22-32 years. This could be related to the inaccessibility to health and safety information, lack of training on health and safety, less work experience, low- level of knowledge and skill towards the work.

As regards to the relationship between level of education of the study group and their exposure to various types of occupational health hazards, the present study had revealed that there was a statistically significant difference between level of education of the study group and their exposure to various types of occupational health hazards. This result is in agreement with Nearkasen et al,. (2002); Bhattacherjee et al., (2003); Smith and Mustrad (2004); Asim et al., (2004); Rhys and Paul (2005); Tadesse and Kumie (2007), who revealed that increased educational levels in the factory had been associated with decreased work related injuries. In addition, Lee (2007) revealed that workers must be assured of their right to a safe and healthy work environment also suggested that there was a need to provide workers with information, education and training so that they would know best how to protect themselves.

Contrary to the present findings Aderaw et al., (2011) who conducted a Case Control Study among Textile Factory Workers in Amhara, Regional State, Ethiopia ,indicated that educational level did not show significant relation with occupational injury. Also, Abd EL-Fatah (2013) revealed that there was no statistical significance differences between exposure to biological and physical health hazards among nurses at Port Said city, Egypt with educational level. This might be due to the fact that education is more likely to increase workers safety and health practice that can prevent them from occupational injuries.

Moreover, the findings of the present study reported that there was no statistical significance difference between sleep hours and exposure to occupational health hazards. These findings are in contrary to Akinori et al., (2005) who conducted a study about Sleep related Risk of Occupational Injury in Japanese Small and Medium Scale Enterprise, and stated that the difficulty in initiating sleep, sleeping poorly at night, sleep insufficiency, and insomnia symptoms were significantly associated with the occurrences of occupational injury. Furthermore, Rhys and Paul (2005), Tadesse and Kumie (2007), Aderaw et al., (2011), revealed that workers who complained from sleep disturbances during work had about two times more likely to report occupational injuries than workers who did not report a problem of sleeping disorders. This might be due to the fact that workers in textile factories were employed in three shifts with eight working hour's interval which might disrupt the sleeping pattern of workers. These sleeping disturbances' problems affect the ability to 
maintain wakefulness and concentration as well as the ability to assess or watch the work environment and working conditions and perform duties safely.

Concerning the relationship between level of education of the study group and their attendance to training courses, the findings of the present study revealed that there was a statically significant difference between level of education of the study group and their attendance to training courses mainly related to occupational health hazard reduction. This might be due to the fact that education was more likely to increase workers safety and health practice that could prevent them from occupational injuries. These findings come in line with Bhattacherjee et al., (2003), Smith and Mustrad (2004) which indicated that, most occupational health and safety studies conducted in developing countries, revealed that the increased educational level had been associated with decreased work-related injuries. In addition, Malik et al., (2010) revealed that educated workers had more knowledge, attitude and there was a direct relationship between education of workers and occupational health and safety knowledge.

On the contrary to these findings Aderaw et al. (2011) found that educational level did not show any statistical significant association with the occurrence of occupational injury.. This difference might be due to the fact that only education by itself alone couldn't reduce occupational injury when the level of hazards was high and the use of reliable techniques and safe work organizations were limited.

\section{Conclusion:}

\section{The conclusions were made from the results of the present study are:}

1- Most of the studied group were exposed to various sources of occupational health hazards (physical, chemical, psychological, and ergonomic hazards) at their work place which resulted in tremendous harmful effects on their health.

2- The highest percentage of the studied group was exposed to psychological hazards while the lowest percentage of them were exposed to physical hazards.

3- There was shortage of personal protective equipment.

4- There were a highly statistically significant differences between exposure of the studied group to various types of occupational health hazards at their work places with the use of personal protective equipment. 


\section{Recommendations:}

In the light of the findings of the present study, the following recommendations are suggested:

1- The need for stressing on the application of International Standard Occupational Health and Safety Assessment Series, in field work to improve occupational health and safety performance for the workers

2- Periodic check up for workers for early detection of occupational hazards to monitor the health status and early case finding.

3- Emphasizing on the importance and usefulness of personal protective equipment to be used in the right way and first aid for the promotion of personal fitness of the workers by health promotion programs.

4- Workers must be trained not only in the proper use of protective equipment, but also in the care and maintenance of that equipments including any pre-fitting, testing, or inspection that may be required.

5- Workers should have access to all information relevant to the hazards through mass media as video tape in easy language to meet most workers' level of education and information relevant to a safe working environment.

6- Health education programs should be developed and carried out by the occupational health nurse to raise the awareness of the workers regarding the bad effect of occupational health hazards, importance of attending training programs, and the proper use of personal protective equipment.

\section{References}

Abd- EL-Fatah, F.A. (2013).Nurse's Occupational hazards at governmental hospitals in Port Said city (Un Published master's thesis) Faculty of nursing, Port Said University, Egypt.

Aderaw Z., Engdaw D. and Tadesse T. (2011).Determinants of Occupational Injury: a case control study among textile factory workers in Amhara Regional State, Ethiopia. J Trop Med; 2011 (2011) :1-8.Avilable at : http://dx.doi.org/10.1155/2011/657275.

Ahn Y.S., Bena JF. and Bailer AJ. (2004). Comparison of Unintentional Fatal Occupational Injuries in the Republic of Korea and the United States. Injury Prevention 2004; 10:199-205.

Akinori N., Tomoko I., Masaya T. and Takashi H. (2005). Sleep-related Risk of Occupational Injuries in Japanese Small and Medium-scale Enterprises. Industrial Health. 43 (43): 89-97.

American Association of Occupational Health Nurses (AAOHN), (2007). Delivery of Occupational and Environmental Health Services, New York, Atlanta Co; 3-11. 
Asim S., Takiar R. and Ramendra N. (2004). An accident risk assessment study of temporary piece rate workers, occupational Medicine Division, National Institute of Occupational Health. India, Industrial Health. 42(2): 240-245.

Baskett R. (2007). Occupational Health Nursing A theoretical model. AAOHN Journal, 40(10); 90-96.

Bhatia P. and Kumar A. (2005). Occupational stress and burnout in industrial employee. Indian Psych. Rev; 64(4): 191-198.

Bhattacherjee A., Chau N., Otero Sierra C. and Legras B. (2003). Relationships of job and some individual characteristics with occupational injuries in employed people. A communitybased study. J Occup Health; 45 (1): 382-391.

Boonmak W., Chanprasit C. and Songkham W. (2009). Occupational Accidents and Risk Behavior among Wooden Game Workers. Journal of Public Health; 39(2): 131-140.

Burkean M. (2009). The American Board for Occupational Health Nurses: Role delineation and validation protect .Occupational Health Nursing; 552-24.

Concha-Barrientos M., Imel ND., Driscoll T. and Steenland NK. (2004). Selected occupational risk factors. In M. Ezzati, A.D. Lopez, A. Rodgers \& C.J.L. Murray (Eds.), Comparative Quantification of Health Risks. Geneva: World Health Organization; P. 1653.

Conn R. and Barclay L. (2008). Health Education in the Workplace, AAOHN Journal 2, (28): 407-412.

David K., Kee-Seng C. and Jeyaratnam, (2005). Textbook of Occupational Medicine practice, $2^{\text {nd }}$ ed., Word Scientific Publisher Company, London; 307-308, 382.

El-Sobky MK. (2008). Study of accidents among workers Helwan cement factories. MD Thesis, Faculty of Medicine, Cairo University; 46.

Feijoo NR. (2004). Occupational stress, job insecurity and stress level. Thematic Oral Session. INTERDISCIPLINARIA; 99(2004): 244-257.Avilable at http:// www.redalyc.org/articulo.oa?id=18009918.

Fleming M. and Lardner R. (2002). Strategies to promote safe behavior as part of a health and safety management system. Contact Research Report; 430-38.

Gupta P. and Ghai, OP. (2007). Textbook of Preventive and Social Medicine, $2^{\text {nd }}$ Ed, New Delhi, CBS Publishers \& Distributors; 520,687.

Haggag M. (1995). The Impact of Child's Labor on His Health Status in Alexandria, Doctoral Thesis, Faculty of Nursing, Alexandria University.

Harris C. (2007). Occupational Health Nursing Practice, 1st Ed; Bristol, Johns Right and Sonsltd; 814.

Jamsion DT., Berman GG. And Measham AR. (2006). Disease control Priorities in Developing Countries. $2^{\text {nd }}$ ed., Washington., D.C. 
Khdair WA., Shamsudin FM. and Subramanim C. (2011). A Proposed Relationship between Management Practices and Leadership Behaviors in The oil and Gas Industry in Iraq. World Review of Business Research; 1(3): 27-45.

Koka V. and Srivastava M. (2012). Occupational health hazards of textile workers of Pali District. Asian Journal of home science; 7 (1): 152-155.

Kotb WA. (2012). Health hazards among workers in Kaha food factory in Kalubya governorate. Un Published Master Thesis faculty of nursing, Benha University.

Lee T. (2007). Implement Safe Work Procedures: Safety and Health Management System Best Answer to Reduce Accidents at the Workplace' in Borneo Post, Friday, $7^{\text {th }}$ ed., December 2007; P.15

Malik N., Maan AA., Pasha TS., Akhtar S. and Ali T. (2010). Role of Hazard Control Measures In occupational health and Safety In the Textile Industry Of Pakistan. Pak .J. Agri. Sci; Vol 47 (1): 72-76. Available at: http://www.pakjas.cpm.pk.

Marmot M. and Blatt PG. (2013). Health Promotion at work places in Tanzania. African newsletter of occupational health and safety. 23(1): 3-23.

Mercury SM., Gemmell CG., Paterson KR. and Maccuish AC. (2009). Changes in Phagocytes Function with Glycogenic Control in Diabetic Patients. J.Clin Patho; 42, 1143-7.

Moore P. (2007). Industrial defenses, Nz. Med.J101; 1827-1628.

Nearkasen C., Marie JM., Lahoucine B. and Christian S. (2002). Relationships between some individual characteristics and occupational accidents in the construction industry: a casecontrol study. J. Occup .Health. 44: 131-139.

Occupational Health and Safety Administration (2006). Proposed Rule and Standard for PPE (Internet), U.S. Department of Labor, Washington DC.

Plog B., Niland J., \& Quinlan P. (2004).Fundamental of factories Hygiene, $4^{\text {th }}$ Ed, Itasca, National Safety Council; 7-29,729-741.

Rantanen J. (2004). A healthy and safe workplace. African Newsletter on Occupational health and safety; 14 (2): 27.

Rhys D. and Paul J. (2005). Trends and context to rates of workplace injury. Health and safety executive .Warwick institute for employment research university of Warwick Coventry.

Rogers B. (2005). Occupational Health Nursing : Concepts and Practice, St Louis, Mosby Elsevier : In Stanhope. M.

Sarok A. and Susil J. (2012). Occupational Hazards in the Workplace: A Case of an Electronic Company in Sama Jaya, Kuching, Sarawak, Malaysia. Asian Journal of Business Research; 2(1): $1-13$. 
Shafik SA., and Abd El-Mohsen AS. (2012). Occupational health: Health Promotion Program to Improve Health Workers in Tourah Cement Factory. Journal of American Science; 8(3): Available at: http://www.americanscience.org.

Sheha EA. (2009). Occupational hazards among workers in Glass manufacture industries. Un Published Master Thesis. Faculty of nursing, Ain Shams University.

Sivarethinamohan $R$. (2010). Industrial relations and labor welfare: Text and cases. $1^{\text {st }}$ ed., New Delhi: PHI Learning Private Limited; P. 226.

Smith PM. and Mustrad CA. (2004). Examining the association between physical work demands and work injuries between men and women. Occup Environ med; 61 (9): 750-756.

Stanhope M. and Lancaster J. (2008). Community \& Public Health Nursing. $7^{\text {th }}$ ed., Mosby, Philadelphia, company. pp. 953:957.

Tadesse T. and Kumie A.(2007). Prevalence and Factors affecting Work -related Injury among workers engaged in Small and Medium Scale Industries In Gondar Wereda, north Gondar Zone, Amhara Regional State, Ethiopia . 21(1): 25-34.

Tarvsainen K., Jolanki R., Forsman Gronholm L., Estlander T., Pfaffli P., Juntunen J. and Kanerva L. (2006): Contact dermatitis journal, 29(3): 119-127.

Tiwari R., Saha A., Parikh J. and Saiyed H. (2004). Injury and injury care among child laborers in gem polishing industries in Jaipur, India. J of Occu Health; 46 (3): 216-219.

WHO (2003). Occupational Health Program of WHO Headquarters, Geneva, Switzerland. The Global Occupational Health Network 2003; pp.1-2. 
Table (1): Socio-demographic Characteristics of the study group

\begin{tabular}{|l|c|c||}
\hline \multicolumn{1}{|c|}{ Demographic Data } & No. & \% \\
\hline Age: & \multicolumn{2}{c|}{} \\
$<20$ & 8 & 8.0 \\
$20-<30$ & 29 & 29.0 \\
$30-<40$ & 32 & 32.0 \\
$\geq 40$ & 31 & 31.0 \\
\hline Range. & \multicolumn{2}{|c|}{$18.0-57.0$} \\
Mean \pm SD. & \multicolumn{2}{|c|}{$34.98 \pm 10.32$} \\
Median & \multicolumn{2}{|c|}{34.50} \\
\hline Marital status: & 21 & 21.0 \\
Single & 71 & 71.0 \\
Married & 1 & 7.0 \\
Divorced & 7 & 1.0 \\
Widowed & \multicolumn{2}{|c}{} \\
\hline Education: & 7 & 7.0 \\
Illiterate & 9 & 9.0 \\
Read and write & 10 & 10.0 \\
Basic education & 66 & 66.0 \\
Secondary and industrial & 8 & 8.0 \\
University & \multicolumn{2}{|c|}{} \\
\hline
\end{tabular}

Table (2): Distribution of the study group, according to work characteristics

\begin{tabular}{|c|c|c|}
\hline Characters of Work & No. & $\%$ \\
\hline $\begin{array}{l}\text { Work Shifts } \\
\text { Morning } \\
\text { Afternoon } \\
\text { More than one shift }\end{array}$ & $\begin{array}{l}42 \\
19 \\
39\end{array}$ & $\begin{array}{l}42.0 \\
19.0 \\
39.0\end{array}$ \\
\hline $\begin{array}{l}\text { Working Hours / Day } \\
\text { Min. - Max. } \\
\text { Mean } \pm \text { SD. } \\
\text { Median }\end{array}$ & \multicolumn{2}{|c|}{$\begin{array}{c}6.0-12.0 \\
8.74 \pm 2.84 \\
7.50\end{array}$} \\
\hline $\begin{array}{l}\text { Years of Experience } \\
\leq 1 \\
2-\leq 5 \\
6-\leq 10 \\
>10\end{array}$ & $\begin{array}{c}7 \\
13 \\
29 \\
52\end{array}$ & $\begin{array}{c}7.0 \\
13.0 \\
29.0 \\
52.0\end{array}$ \\
\hline $\begin{array}{l}\text { Min. }- \text { Max. } \\
\text { Mean } \pm \text { SD. } \\
\text { Median }\end{array}$ & \multicolumn{2}{|c|}{$\begin{array}{c}0.50-33.0 \\
11.80 \pm 7.33 \\
11.0\end{array}$} \\
\hline $\begin{array}{l}\text { Position during Work: } \\
\text { Sitting } \\
\text { Standing } \\
\text { Bending for long periods }\end{array}$ & $\begin{array}{c}36 \\
57 \\
7\end{array}$ & $\begin{array}{c}36.0 \\
57.0 \\
7.0\end{array}$ \\
\hline
\end{tabular}




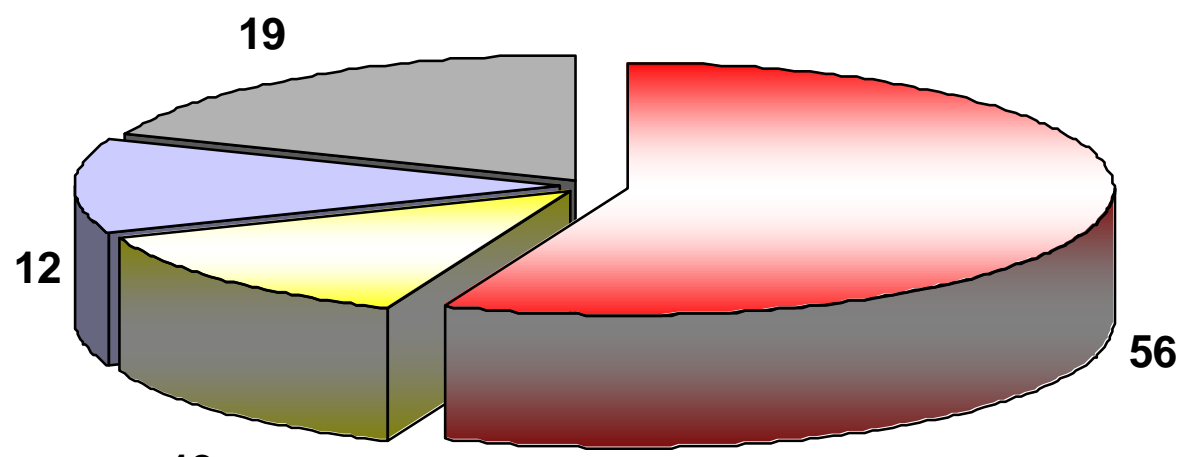

13

Fig. (1): Distribution of the study group according to their attendance to training courses

Table (3): Distribution of the study group according to their exposure to occupational health hazards

\begin{tabular}{||l|c|c|c|c||}
\hline \multirow{2}{*}{ Occupational Hazards } & \multicolumn{2}{|c|}{ Exposed } & \multicolumn{2}{c||}{ Not exposed } \\
\cline { 2 - 6 } & NO & $\%$ & NO & $\%$ \\
\hline Physical hazards & 64 & 64.0 & 36 & 36.0 \\
Chemical hazards & 74 & 74.0 & 26 & 26.0 \\
Mechanical hazards & 72 & 72.0 & 28 & 28.0 \\
Psychological hazards & 77 & 77.0 & 23 & 23.0 \\
\hline
\end{tabular}

Responses are not mutually exclusive 
Table (4): Distribution of the study group according to their report about availability of personal protective measures

\begin{tabular}{||l|c|c|c|c||}
\hline \multirow{2}{*}{ Safety Protective Measures } & \multicolumn{2}{|c|}{$\begin{array}{c}\text { Available } \\
\text { (Actually } \\
\text { used) }\end{array}$} & \multicolumn{2}{c|}{ Not Available } \\
\cline { 2 - 5 } & No. & $\%$ & No. & $\%$ \\
\hline Overall Uniform & 8 & 8.0 & 92 & 92.0 \\
Head Cover (cap) & 31 & 31.0 & 69 & 69.0 \\
Ear muffs & 5 & 5.0 & 95 & 95.0 \\
Gloves & 8 & 8.0 & 92 & 92.0 \\
Protective Apron & 27 & 27.0 & 73 & 73.0 \\
Safety boots & 29 & 29.0 & 71 & 71.0 \\
Respiratory Mask & 26 & 26.0 & 74 & 74.0 \\
\hline \hline
\end{tabular}

Table (5): Relationship between exposure the study group to occupational health hazards and the use of personal protective equipment

\begin{tabular}{|c|c|c|c|c|c|c|}
\hline \multirow{3}{*}{ Items } & \multicolumn{4}{|c|}{ Equipment } & \multirow{3}{*}{$\chi^{2}$} & \multirow{3}{*}{$\mathrm{P}$} \\
\hline & \multicolumn{2}{|c|}{ Not used } & \multicolumn{2}{|c|}{ Used } & & \\
\hline & No & $\%$ & No & $\%$ & & \\
\hline \multicolumn{7}{|l|}{ Physical Hazards: } \\
\hline Not Exposed & 31 & 23.8 & 5 & 12.2 & 10.138 & $0.001 *$ \\
\hline Exposed & 35 & 42.2 & 29 & 21.8 & & \\
\hline \multicolumn{7}{|l|}{ Chemical Hazards: } \\
\hline Not Exposed & 11 & 17.2 & 15 & 8.8 & 8.789 & $0.003 *$ \\
\hline Exposed & 55 & 48.8 & 19 & 25.2 & & \\
\hline \multicolumn{7}{|l|}{ Mechanical Hazards: } \\
\hline Not Exposed & 11 & 18.5 & 17 & 9.5 & 12.368 & $0.000 *$ \\
\hline Exposed & 55 & 47.5 & 17 & 24.5 & & \\
\hline \multicolumn{7}{|l|}{ Psychological hazards: } \\
\hline Not Exposed & 9 & 15.2 & 14 & 7.8 & 9.610 & $.002 *$ \\
\hline Exposed & 57 & 50.8 & 20 & 26.2 & & \\
\hline
\end{tabular}


Table (6): Relationship between level of education of the study group and their attendance to training courses

\begin{tabular}{|c|c|c|c|c|c|c|c|c|c|c|c|c|c|c|c|}
\hline \multirow{4}{*}{$\begin{array}{c}\text { Education } \\
\text { Level }\end{array}$} & \multicolumn{15}{|c|}{ Training Courses } \\
\hline & \multicolumn{4}{|c|}{$\begin{array}{c}\text { Occupational } \\
\text { Hazards }\end{array}$} & \multirow[t]{3}{*}{$\mathbf{P}$} & \multicolumn{4}{|c|}{$\begin{array}{l}\text { Accidents } \\
\text { prevention }\end{array}$} & \multirow[t]{3}{*}{$\mathbf{P}$} & \multicolumn{4}{|c|}{ First Aid } & \multirow[t]{3}{*}{$\mathbf{P}$} \\
\hline & \multicolumn{2}{|c|}{ No } & \multicolumn{2}{|c|}{ Yes } & & \multicolumn{2}{|c|}{ No } & \multicolumn{2}{|c|}{ Yes } & & \multicolumn{2}{|c|}{ No } & \multicolumn{2}{|c|}{ Yes } & \\
\hline & No & $\%$ & No & $\%$ & & No & $\%$ & No & $\%$ & & No & $\%$ & No & $\%$ & \\
\hline Illiterate & 6 & 6.6 & 1 & 11.1 & & 6 & 6.7 & 1 & 10.0 & & 6 & 6.9 & 1 & 7.7 & \\
\hline $\begin{array}{l}\text { Read and } \\
\text { Write }\end{array}$ & 6 & 6.6 & 3 & 3.3 & $004^{*}$ & 9 & 10.0 & 0 & 0.0 & 703 & 8 & 9.2 & 1 & 7.7 & 000 \\
\hline $\begin{array}{c}\text { Basic } \\
\text { Education }\end{array}$ & 13 & 14.3 & 0 & 0.0 & & 11 & 12.2 & 2 & 20.0 & & 11 & 12.6 & 2 & 15.4 & \\
\hline $\begin{array}{l}\text { Secondary } \\
\text { Education }\end{array}$ & 63 & 69.2 & 3 & 33.3 & & 60 & 66.7 & 6 & 60.0 & & 57 & 65.5 & 9 & 69.2 & \\
\hline $\begin{array}{l}\text { University } \\
\text { Education }\end{array}$ & 3 & 3.3 & 2 & 22.2 & & 4 & 4.4 & 1 & 10.0 & & 5 & 5.7 & 0 & 0.0 & \\
\hline
\end{tabular}

Table (7): Relationship between personal characters of the study group and their exposure to various types of occupational health hazards

\begin{tabular}{|c|c|c|c|c|c|c|c|c|c|c|c|c|c|c|c|c|c|c|c|c|}
\hline \multirow{3}{*}{ Personal characters } & \multicolumn{4}{|c|}{ Physical hazards } & \multirow[b]{2}{*}{$P$} & \multicolumn{4}{|c|}{ Chemical hazards } & \multirow[b]{2}{*}{$P$} & \multicolumn{4}{|c|}{ Psychological hazards } & \multirow[b]{2}{*}{$P$} & \multicolumn{4}{|c|}{ Mechanical hazards } & \multirow[b]{2}{*}{$P$} \\
\hline & \multicolumn{2}{|c|}{$\begin{array}{c}\text { Not } \\
\text { Exposed } \\
\mathrm{N}=36\end{array}$} & \multicolumn{2}{|c|}{$\begin{array}{c}\text { Exposed } \\
\mathrm{N}=64\end{array}$} & & \multicolumn{2}{|c|}{$\begin{array}{c}\text { Not } \\
\text { Exposed } \\
N=26\end{array}$} & \multicolumn{2}{|c|}{$\begin{array}{c}\text { Exposed } \\
\mathrm{N}=74\end{array}$} & & \multicolumn{2}{|c|}{$\begin{array}{c}\text { Not } \\
\text { Exposed } \\
\mathrm{N}=23\end{array}$} & \multicolumn{2}{|c|}{$\begin{array}{c}\text { Exposed } \\
\mathrm{N}=77\end{array}$} & & \multicolumn{2}{|c|}{$\begin{array}{c}\text { Not } \\
\text { Exposed } \\
\mathrm{N}=\mathbf{2 8}\end{array}$} & \multicolumn{2}{|c|}{$\begin{array}{c}\text { Exposed } \\
\mathrm{N}=72\end{array}$} & \\
\hline & No & $\%$ & No & $\%$ & & No & $\%$ & No & $\%$ & & No & $\%$ & No & $\%$ & & No & $\%$ & No & $\%$ & \\
\hline \multicolumn{21}{|l|}{ Age: } \\
\hline$-<20$ & 8 & 22.2 & 0 & 0.0 & & 5 & 19.2 & 3 & 4.00 & & 2 & 8.7 & 6 & 7.8 & & 5 & 17.9 & 3 & 4.00 & \\
\hline $20-30$ & 4 & 11.1 & 25 & 39.0 & $.000 *$ & 14 & 53.8 & 15 & 20.3 & $.000^{*}$ & 14 & 60.9 & 15 & 19.5 & $.000^{*}$ & 16 & 57.1 & 13 & 18 & $.000^{*}$ \\
\hline $30-40$ & 0 & 0.0 & 32 & 50.1 & & 7 & 26.9 & 25 & 33.8 & & 7 & 30.4 & 25 & 32.5 & & 7 & 25.0 & 25 & 43.7 & \\
\hline$\geq 40$ & 24 & 66.7 & 7 & 10.9 & & 0 & 0 & 32 & 43.2 & & 0 & 0 & 32 & 41.6 & & 0 & 0 & 32 & 44.4 & \\
\hline \multicolumn{21}{|l|}{ Education: } \\
\hline Illiterate & 7 & 19.4 & 0 & 0.0 & & 5 & 19.2 & 2 & 2.7 & & 2 & 8.7 & 5 & 6.5 & & 4 & 14.3 & 3 & 4.2 & \\
\hline Basic education & 5 & 13.9 & 14 & 21.9 & $.001^{*}$ & 9 & 34.6 & 10 & 13.5 & $.004^{*}$ & 9 & 39.1 & 10 & 12.9 & .032 & 12 & 42.9 & 7 & 9.7 & $.000 *$ \\
\hline Secondary & 24 & 66.7 & 42 & 65.6 & & 10 & 38.5 & 56 & 75.7 & & 10 & 43.5 & 56 & 72.3 & & 10 & 35.7 & 56 & 7.8 & \\
\hline University & 0 & 0.0 & 8 & 12.5 & & 2 & 7.7 & 6 & 81.1 & & 2 & 8.7 & 6 & 7.8 & & 2 & 7.1 & 6 & 8.3 & \\
\hline \multicolumn{21}{|l|}{ Sleep Hours: } \\
\hline Enough & 13 & 36.1 & 25 & 39.1 & & 4 & 15.4 & 29 & 39.2 & & 4 & 17.4 & 29 & 37.7 & & 4 & 14.3 & 29 & 40.3 & \\
\hline Not Enough & 23 & 63.9 & 39 & 60.9 & .662 & 22 & 84.6 & 45 & 60.8 & .030 & 19 & 82.6 & 48 & 62.3 & .017 & 24 & 85.7 & 43 & 59.7 & .581 \\
\hline
\end{tabular}




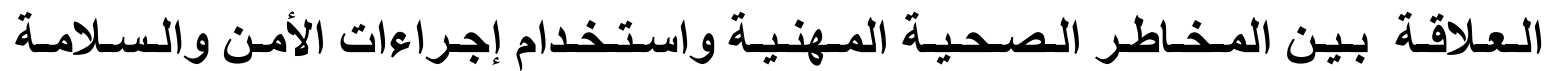

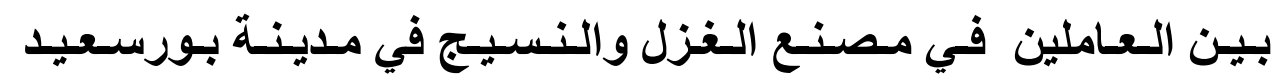

عطية مجاهد مجاهد إبراهيم، ا.د. عفت محمه القرملاوي، ا.د. هـن علي عبل الواحد،

\section{د.دفاطمة الإمام حافظ}

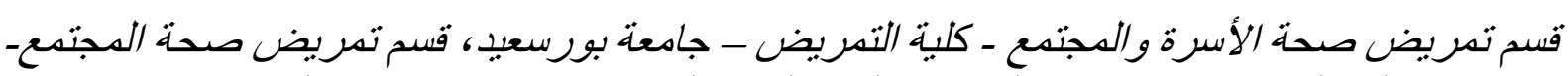

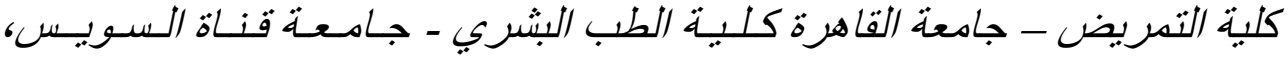

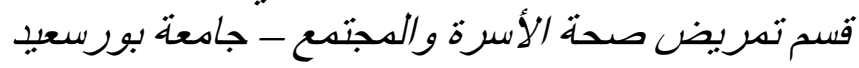

\section{الخلاصة}

يتعرض العمال في مصانع الغزل والنسيج للمخاطر المختلفة، والتي قد يكون لها آثار ضـارة كبيرة على صـحتهم. وكـان الهـدف مـن خـلال هذه الدر اسـة هو تقيبم العلاقـة بين المخـاطر الصـحية المهنيـة و استخدام إجر اءات الأمسن و السـلامة بين العـلين في مصـنع الغزل و النسيج في مدينـة بورسـعيد ، و اشتملت هذه الدر اسة الوصفية علي مائة عامل في مصنع الغزل و النسيج بمدينـة بورسعيد. وتم جمـع البيانات باستخدام ثلاث أدو ات و هي: استمارة استبيان - استمارة ملاحظة للعمال و استمارة لتقييم بيئة

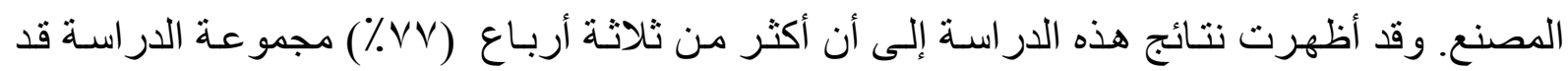

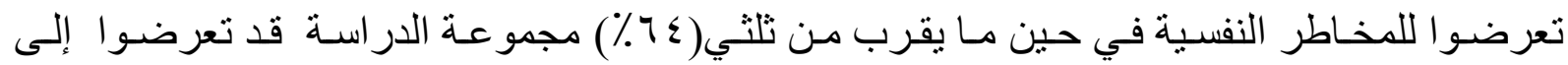

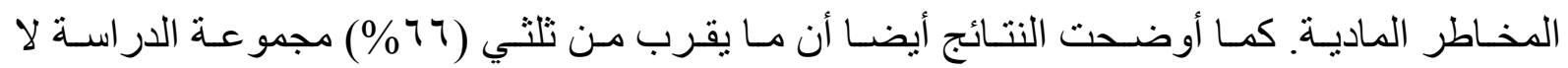
يسـتخدوا أدوات الوقايـة. وخلصـت الدراسـة إلى أن هنـالك فروق ذات دلالـة إحصـائية بـين تعـرض مجمو عـة الدر اسـة لأنواع مختلفة مـن المخـاطر الصـحية المهنيـة و عدم ارتـاء أدوات و أجهزة الوقايـة اللازمة. وقد أوصت الدراسة بضرورة تطبيق معايير الصحة و السلامة المهنيـة الدوليـة بين العمال في بيئة العمل وذلك لتحسين أداؤهم صحيا ومهنيا.كما أوصت الدر اسة أيضا بالتأكيد علي ضرورة وأهميـة استخدام أدوات و أجهزة الوقاية بين العمال بالطريقة الصحيحة. الكلمات الدالةه المخاطر الصحبة الدهنبة، أدوات الوقابة الثخصية، مصنع الغزل والنسيج 